CUAJ honors its members and friends who have passed away. We invite colleagues of the deceased to submit brief remembrances. Please limit your notice to 200 words. Send your notice to journal@cua.org or fax it to 514-395-1664.
Cite as: Can Urol Assoc J 2021;15(12):430. http://dx.doi.org/10.5489/ cuaj.7696

\section{Dr. Malcolm S. McPhee}

It was with sadness that I learned that Dr. Malcolm McPhee passed away suddenly on November 4, 2021, surrounded by his family. His son Christopher reported that he slept away peacefully.

A mentor to many of us in the urological community, Malcolm was a Queen's graduate in medicine and did his training in urology at the University of Alberta, with a subsequent fellowship at Memorial Sloan Kettering in uro-

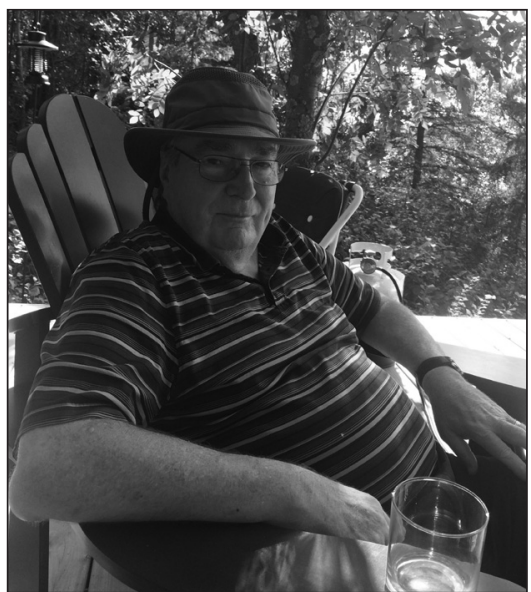
oncolgy. He was the surgical director of the Cross Cancer Institute for many years. In this role, one of his greatest accomplishments was the development of hospice care with Dr. Neil McDonald.

Malcolm started his research career working in the laboratory of Dr. William (Bill) Lakey, studying kidney disease and hypertension. This was the beginning of a lifelong interest in research at the Surgical Medical Research Institute (SMRI). Through this research interest, he met Dr. John Tulip of electrical engineering and developed a strong interest in developing lasers for surgical application. Malcolm also partnered with Dr. Donald Chapman (radiobiology) to develop research initiatives for urology residents during their research year of training at the Cross Cancer Institute while he was program director and divisional director of the University of Alberta urology program.

He served the urological community in other ways as well, including via his work with the Canadian Urological Association (CUA), for which he served as president in 1986-87. Malcolm also had significant roles with the Royal College of Physicians and Surgeons of Canada.

Highly respected by all, Malcolm was always proud of the accomplishments of his trainees and his family. He loved to play the piano, paint, fly fish, and fly his glider planes. But the most memorable aspect of Malcolm was his good nature, kindness, and boyish grin. 